\title{
Effect of Water Extract Originated from Different Part of Russian Knapweed (Acroptilon repens L.) on Growth of Purslane (Portulaca oleracea L.)
}

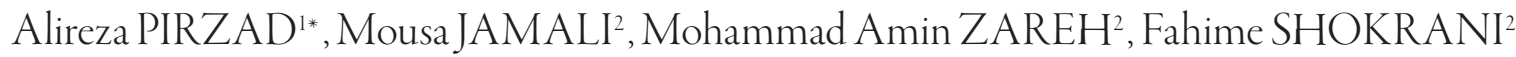 \\ ${ }^{1}$ Urmia University, Department of Medicinal and Industrial Plants, Institute of Biotechnology, \\ Urmia,Iran; a.pirzad@urmia.ac.ir ("correspondingauthor) \\ ${ }^{2}$ Urmia University, Department of Agronomy and Plant Breeding, Faculty of Agriculture, Urmia, Iran
}

\begin{abstract}
To evaluate probable allelopathic effect of water extract originated from different parts of russian knapweed (Acroptilon repens $\mathrm{L}$.) on growth of purslane (Portulaca oleracea L.), a factorial experiment was conducted based on randomized complete block design with three replications at greenhouse condition in 2011. Treatments were water extract concentrations $(0,5,10,15$ and 20 percent) obtained from different part of russian knapweed (aerial part, flower and root). Results showed the significant effect of extract type on seedling length, and extract concentration on shoot length, root length and seedling length. Interaction effect between extract type and concentration on the ratio of root/shoot length, seedling fresh weight, seedling dry weight and germination percentage was significant, too. Means comparison indicated that the longest root $(3.55 \mathrm{~cm})$, shoot $(4.65 \mathrm{~cm})$ and seedling $(8.20 \mathrm{~cm})$ were obtained from control treatment, reducing with higher concentration of extract. The longest shoot $(6.95 \mathrm{~cm})$ belonged to extract originated from russian knapweed flowers. The highest ratio of root/shoot length $(0.73)$, seedling fresh weight $(0.61 \mathrm{~g})$ and seedling dry weight $(0.044 \mathrm{~g})$ belonged to control treatment. In general, increasing of extract concentration caused in reduction of germination and seedling traits. Meanwhile, extracts of aerial part had more sever reducing effect than root and flower extracts.
\end{abstract}

Keywords: aerial part, allelopathy, flower, germination, root, seedling, weed

\section{Introduction}

Portulaca oleracea L. (Portulacaceae) is a widely distributed weed. It has been used as a folk medicine in many countries as a diuretic, febrifuge, antiseptic, antispasmodic and vermifuge. It exhibits a wide range of pharmacological effects, including antibacterial (Zhang et al., 2002), analgesic, anti-inflammatory (Chen, 2000). Portulaca is the only genus that remains in Portulacaceae Family following the proposal of splitting the family into four Doweld (Nyffeler and Eggli, 2010).

Allelopathy interactions are primarily based on the ability of certain plant species to produce secondary chemical compounds, that exert some sort of biological effects on other organisms, many of which are still unknown (Waller, 2004). Allelopathy bioassays are typically done in controlled settings, which often differ substantially from natural conditions. These methods usually involve generating leachate from allelopathic plants and subsequently testing them on seedlings (Wilson and Rice, 1968). Such methods have led to identification of allelopathic root exudates from three knapweeds; diffuse (Vivanco et al., 2004), russian knapweed (Stermitz et al., 2003), and spotted (Bais et al., 2003).

Russian knapweed (Acroptilon repens) is an exotic invasive plant in North America and has been suspected to be allelopathic (Fletcher and Renney, 1963). Several natural products from this plant have negative effects on other organisms. Phytochemicals from russian knapweed are harmful to other plants (Stermitz et al., 2003), and bacteria (Norouzi-Arasi et al., 2006).

Based on our knowledge, there are no reports on the allelopathic effect of russian knapweed, especially different parts of this plant, on the germination and seedling growth of purslane. Then, the main objective of this study is allelopathic effect of water extract of aerial parts, root and flower of Acroptilon repens on germination and seedling growth of Portulaca oleracea.

\section{Material and methods}

To evaluate probable allelopathic effect of water extract originated from different part of russian knapweed (Acroptilon repens L.) on growth of purslane (Portulaca oleracea L.), a factorial experiment was conducted based on randomized complete block design with three replications at the greenhouse condition at the Faculty of Agriculture, Urmia University with latitude of $37.53^{\circ} \mathrm{N}, 45.08^{\circ} \mathrm{E}$ and $1320 \mathrm{~m}$ above sea. Treatments were water extract concentrations $(0,5,10,15$ and 20 percent) obtained from different part of russian knapweed (aerial part, flower and root). Each of the dishes 100 seeds were placed on filter 
paper and then irrigation with $5 \mathrm{ml}$ of water extract, and then kept inside the incubator at temperature $25^{\circ} \mathrm{C}$. Seed germination was investigated every day and samples of pot were harvested at 15 days after seed germination. The plant samples were separated into root and shoot the dry weight was recorded after drying of samples in an oven at $70^{\circ} \mathrm{C}$ for 72 hours.

The following measurements were recorded at the flowering stage on 10 repetitive plants in each treatment per replication: root length $(\mathrm{cm})$, shoot length $(\mathrm{cm})$, seedling length $(\mathrm{cm})$, ratio of root/shoot length and germination percentage $(\%)$.

\section{Statistical analysis}

Analysis of variance (ANOVA) on data was performed using the general linear model (GLM) procedure in the SAS software (SAS Institute, 2000). The Student-Neuman Keul's test (SNK) was applied to compare treatment means using the MSTATC software package.

\section{Results and discussion}

Results of analysis of variance (ANOVA) showed the significant effect of extract type on seedling length $(p \leq 0.01)$, and extract concentration on shoot length, root length and seedling length $(p \leq 0.01)$. Interaction effect between extract type and concentration on ratio of root/ shoot length and germination percentage $(p \leq 0.01)$, seedling fresh weight and seedling dry weight $(p \leq 0.05)$ was significant, too (Tab. 1).

Means comparison revealed that the longest shoot $(4.65 \mathrm{~cm})$ was obtained from control treatment. Five percent of water extract concentrations produced the same shoot length with the longest one (Fig. 1A).

The longest root $(3.55 \mathrm{~cm})$ and seedling $(8.20 \mathrm{~cm})$ was observed in control treatment followed by higher concentration of extract 5, 10, 15 and $20 \%$ of extract. The shortest $\operatorname{root}(1.83 \mathrm{~cm})$ and seedling length $(5.09 \mathrm{~cm})$ was observed in extract concentrations 20\% (Fig. 1B and 1C).

Non-significant effect of extract type on shoot and root length led to one group of treatments in term these components of seedling length (Tab. 1).
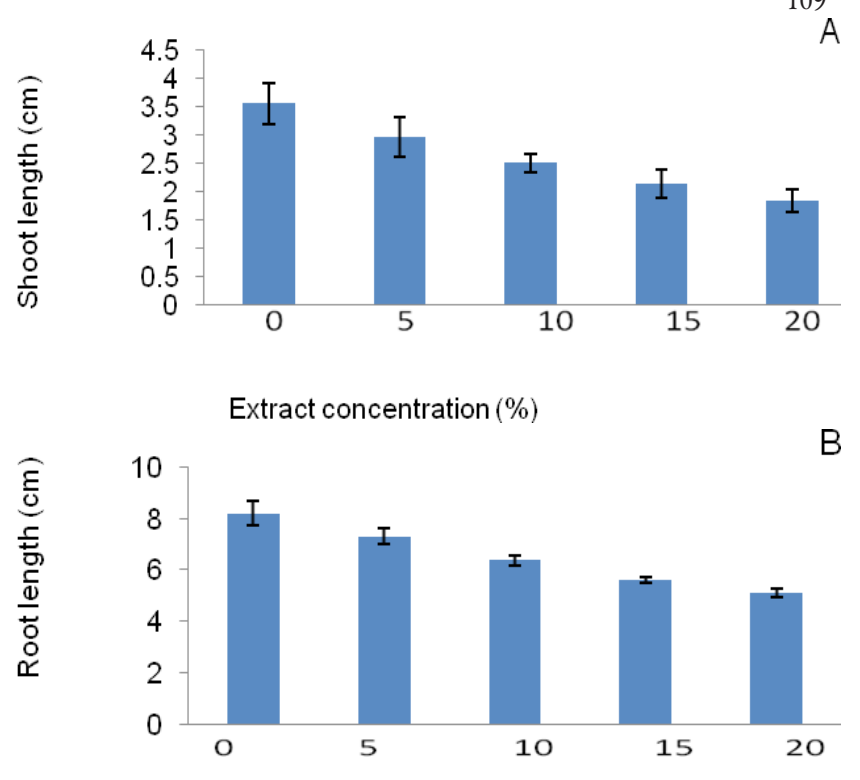

Extract concentration (\%)

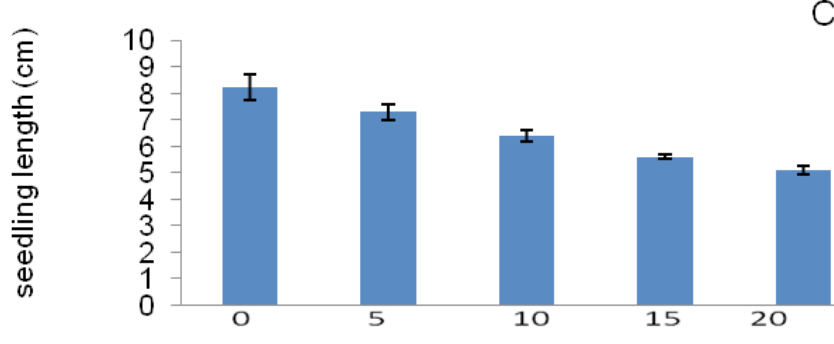

\section{Extract concentration (\%)}

Fig. 1. Effect of extract concentration different part of russian knapweed (Acroptilon repens L.) on stem, root and seedling length of purslane (Portulaca oleracea L.)

Means comparison revealed that the longest stem $(6.95$ $\mathrm{cm}$ ) belonged to extract originated from russian knapweed flowers that had no different extract originated from russian knapweed aerial part and root. The lowest seedling length $(6.21 \mathrm{~cm})$ belonged to extract originated from russian knapweed aerial part, that no different by extract originated from root (Fig. 2).

Tab. 1. Effect of water extract originated from different part of russian knapweed (Acroptilon repens L.) on growth of purslane (Portulaca oleracea L.)

\begin{tabular}{|c|c|c|c|c|c|c|c|c|}
\hline \multirow{2}{*}{$\begin{array}{l}\text { Source of } \\
\text { variation }\end{array}$} & \multirow[b]{2}{*}{ df } & \multicolumn{7}{|c|}{ Means Squares (MS) } \\
\hline & & $\begin{array}{c}\text { Germination } \\
\text { percentage }\end{array}$ & $\begin{array}{l}\text { Shoot } \\
\text { length }\end{array}$ & $\begin{array}{r}\text { Root } \\
\text { length }\end{array}$ & $\begin{array}{c}\text { Root/shoot } \\
\text { length }\end{array}$ & $\begin{array}{l}\text { Seedling } \\
\text { length }\end{array}$ & $\begin{array}{c}\text { Seedling } \\
\text { fresh weight }\end{array}$ & $\begin{array}{c}\text { Seedling } \\
\text { dry weight }\end{array}$ \\
\hline Extract Type (A) & 2 & 2.91 & 1.23 & 0.61 & 0.008 & $3.50^{* *}$ & 0.00004 & 0.013 \\
\hline Extract concentrations (B) & 4 & $29.63^{* *}$ & $5.59^{* *}$ & $7.51^{* *}$ & $0.065^{* *}$ & $25.98^{* *}$ & $0.0004^{* *}$ & $0.092^{* *}$ \\
\hline $\mathrm{A}^{*} \mathrm{~B}$ & 8 & $12.39^{* *}$ & 0.48 & 0.085 & $0.018^{* *}$ & 0.085 & $0.00009^{*}$ & $0.19^{*}$ \\
\hline Replication & 4 & 7.34 & 0.37 & 0.048 & 0.008 & 0.39 & 0.000028 & 0.028 \\
\hline Error & 56 & 4.17 & 0.41 & 0.042 & 0.0027 & 0.58 & 0.000020 & 0.008 \\
\hline \multicolumn{2}{|l|}{ Coefficient of variance (\%) } & 12.66 & 16.55 & 7.99 & 7.92 & 11.77 & 13.60 & 17.2 \\
\hline
\end{tabular}

${ }^{*}$ and ${ }^{* *}$ significant at $p \leq 0.05, \mathrm{p} \leq 0.01$, respectively; $\mathrm{df}$, degree of freedom 


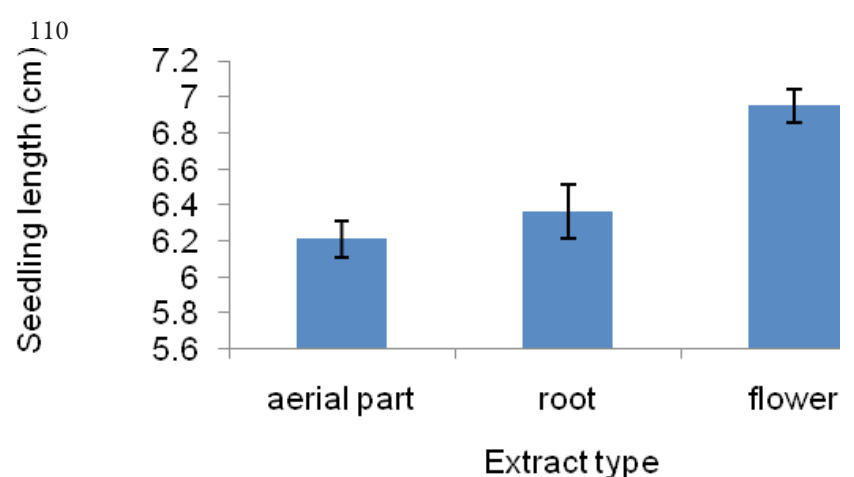

Fig. 2. Effect of water extract originated from different part of russian knapweed (Acroptilon repens L.) on seedling length of purslane (Portulaca oleracea L.)
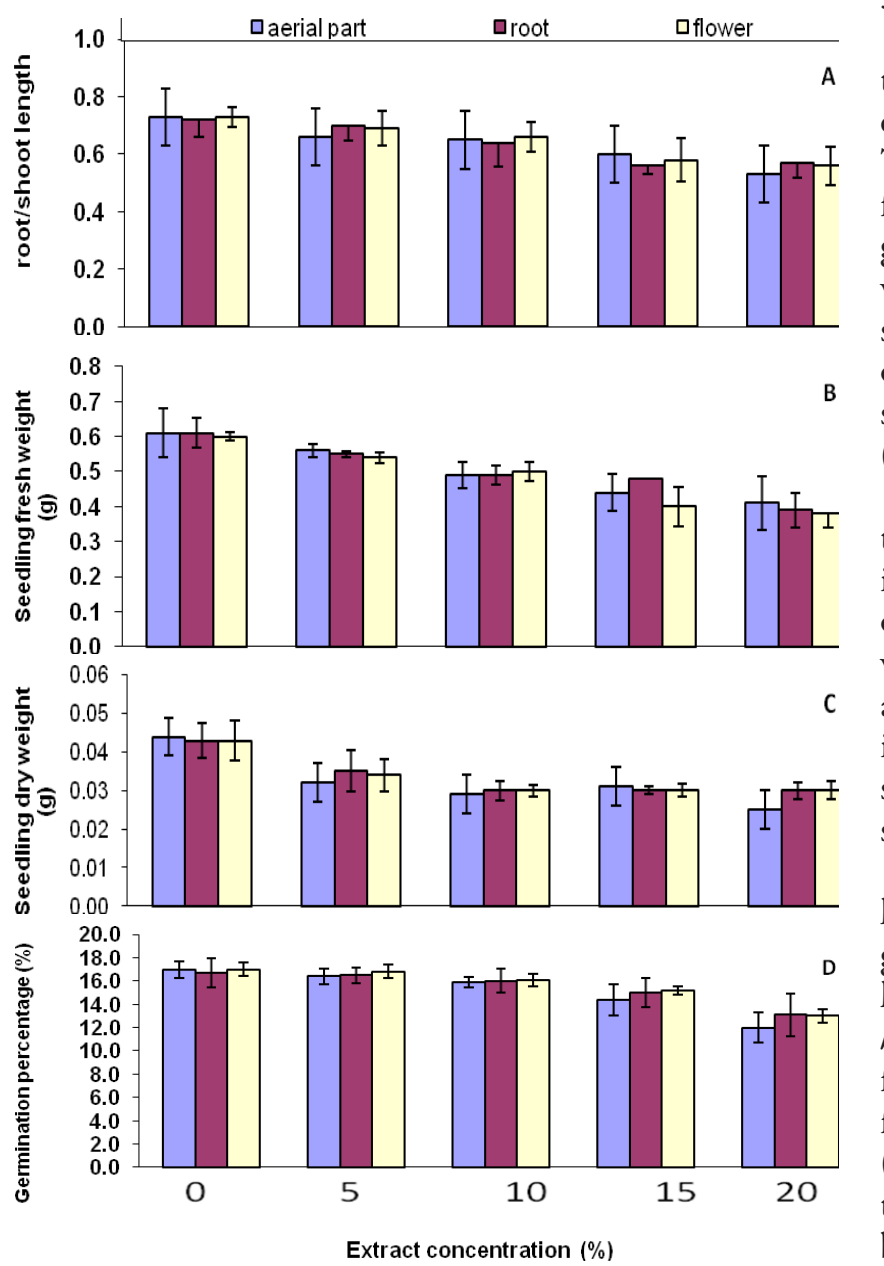

Fig. 3. Means comparison of extract type and concentration on ratio of root/shoot length, seedling fresh and seedling dry weight and germination percentage in Portulaca oleracea L.

Significant interaction effect between extract type and concentration revealed that the maximum ratio of root/ shoot length (0.73) was obtained from control treatment. And the minimum ratio of root/shoot length (0.53) was observed in $20 \%$ extract concentrations obtained from aerial part of russian knapweed. This ratio was reduced along with increasing concentrations of all extract type. But, this reduction was the same in extracts originated from aerial part, root and flower (Fig. 3A).

The greatest seedling fresh weight $(0.61 \mathrm{~g})$ and seedling dry weight $(0.44 \mathrm{~g})$ belonged to control treatment. The smallest seedling fresh weight $(0.38 \mathrm{~g})$ and seedling dry weight $(0.025 \mathrm{~g})$ were occurred at purslane plants that treated with $20 \%$ concentration of flower and aerial part extraction, respectively. Descending trend in fresh weight of seedling was observed in higher concentration, so the same slope in with aerial part, flower and root extract. Despite of the same descending in seedling dry weight, a great downfall was occurred in $5 \%$ of concentration (Fig. $3 \mathrm{~B}$ and $3 \mathrm{C}$ ).

The highest germination percentage (17\%) was obtained from control treatment, which had no significant difference with 5 and $10 \%$ of aerial part, flower and root. The lowest germination percentage (12\%) was obtained from $20 \%$ concentrations of aerial part. The response of germination percent (reduction) was occurred at $15 \%$ of water extract and though the severe reduction was observed in $20 \%$ of extract (Fig. 3D). At all, reducing effect of extract on germination (Fig. 3C) was begun later than seedling growth traits like length (Fig. 3A) and weight (Fig. 3B and 3C).

Russian knapweed (Acroptilon repens) secretes a phytotoxic flavonoid, 7,8-benzoflavone. This chemical was identified under soil-free conditions and caused toxicity in other species at $100 \mathrm{mg} \mathrm{m}^{-1}$ (Stermitz et al., 2003). Flavonoids are generally considered to inhibit germination and cell growth (Berhow and Vaughn, 1999). Allelochemical release early in the season could affect other species at susceptible life stages (e.g., germinating seeds and young seedlings) (Weir et al., 2003).

In addition to temporal and seasonal variation in allelochemical production, differences may exist among genotypes, populations, or plants with differing ages. Age has been shown to affect allelopathic potential in Pinus halepensis (Fernandez et al., 2006). Abiotic and biotic factors differ with location and these may have strong influences on the production of allelopathic compounds (Einhellig, 1999). Körner and Nicklish (2002) found that the allelopathic algal growth inhibition was dependent on biomass of Myriophyllum spicatum. In the present study, the allelopathic effects varied with the initial algal concentrations since the weights of submerged plants were fixed. Many of the phytotoxic substances suspected of causing germination and growth inhibition have been identified from plant tissues and soils. These substances are termed allelochemics (Whittaker and Feeny, 1977).

Pirzad et al. (2010) reported that effects of water extracts of sage and white worm wood on germination and seedling growth of purslane, the maximum fresh and dry seedling weight of purslane were obtained from untreated control. 


\section{Conclusions}

The present findings finding indicated significant effect of extract concentration of russian knapweed on all studied traits of germination and seedling growth of purslane. But extract type had only significant effect on seedling length that emphasize to importance of concentration of extract. It seems all effective secondary metabolites with probable allelopathic effect, was produced in all parts of russian knapweed plants, because of non significant effect of extract type on more traits. However, significant interaction effect between extract type and concentration on germination percent, ratio of root/shoot length, seedling fresh and dry weight showed non uniform trends of these traits along with extract concentration increasing of each type of extract (originated from aerial part, root and flower). While, seedling length of purslane showed significant and ascending trend in respective treat by extract of aerial part, root and flower. In conclusion the seedling growth reduced by higher concentrations of all extract types.

\section{References}

Bais HP, Vepachedu R, Gilroy S, Callaway RM, Vivanco JM (2003). Allelopathy and exotic plant invasion: from molecules and genes to species interactions. Science 301:1377-1380.

Berhow MA, Vaughn SF (1999). Higher plant flavonoids: biosynthesis and chemical ecology, 423-438 p. In: Inderjit Dakshini, KMM, Foy CL (Eds.). Principles and Practices in Plant Ecology: Allelochemical Interactions. CRC Press LLC, Boca Raton, FL.

Chen DCh (2000). Manual of standard compounds of traditional chinese medicine, 109 p. China Medico-Pharmaceutical Science and Technology Press, Beijing.

Einhellig FA (1999). An integrated view of allelochemicals amid multiple stresses, 479-494 p. In: Inderjit, Dakshini KMM, Foy CL (Eds.). Principles and Practices in Plant Ecology: Allelochemical Interactions. CRC Press LLC, Boca Raton.

Fernandez C, Lelong B, Vila B, Mevy JP, Robles C, Greff S, Dupouyet S, Bousquet-Melou A (2006). Potential allelopathic effect of Pinus halepensis in the secondary succession: an experimental approach. Chemoecology 16:97-105.
Fletcher RA, Renney AJ (1963). A growth inhibitor found in Centaurea spp. Can J Plant Sci 43:475-481.

Körner S, Nicklisch A (2002). Allelopathic growth inhibition of selected phytoplankton species by submerged macrophytes. J Phycol 38:862-871.

Norouzi-Arasi H, Yavari I, Chalabian F, Kiarostami V, Ghaffarzadeh F, Nasirian A (2006). Chemical constituents and antimicrobial activities of the essential oil of Acroptilon repens (L.) DC. Flav Frag J 21:247-249.

Nyffeler R, Eggli U (2010). Disintegrating Portulacaceae: A new familial classification of the suborder Portulacineae (Caryophyllales) based on molecular and morphological data. Taxon 59:227-240.

Pirzad A, Ghasemian V, Darvishzadeh R, Sedghi M, Hassani A, Onofri A (2010). Allelopathy of sage and white wormwood on purslane germination and seedling growth. Not Sci Biol 2(3):91-95.

SAS Institute (2000). SAS User's Guide Version 8. SAS Institute, Cary, NC.

Stermitz FR, Bais HP, Foderaro TA, Vivanco JM (2003). 7,8-Benzoflavone: a phytotoxin from root exudates of invasive Russian knapweed. Phytochem 64:493-497.

Vivanco JM, Bais H.P, Stermitz, FR, Thelen GC, Callaway RM (2004). Biogeographical variation in community response to root allelochemistry: novel weapons and exotic invasion. Ecol Lett 7:285-292.

Waller GR (2004). Introduction-reality and future of allelopathy. 1-12 p. In: Macias FA, Galindo JCG, Molinillo JMG, Culter HG (Eds.). Allelopathy, Chemistry and Mode of Action of Allelochemicals. CRC Press, New York, USA.

Weir TL, Bais HP, Vivanco JM (2003). Intraspecific and interspecific interactions mediated by a phytotoxin, catechin, secreted by the roots of Centaurea maculosa (spotted knapweed). J Chem Ecol 29:2397-2412.

Whittaker DC, Feeny PP (1977). Allelochemicals: chemical interactions between species. Science 171:757-770.

Wilson RE, Rice EL (1968). Allelopathy as expressed by Helianthus annuus and its role in old-field succession. Bull Torrey Bot Club 95:432-448.

Zhang XJ, Ji YB, Qu ZhY, Xia JCh, Wang L (2002). Experimental studies on antibiotic functions of Portulaca oleracea L. in vitro. Chinese J Microecol 14 (5): 277-280. 